\title{
Invitation to Gold 2012, Tokyo
}

\author{
M. Haruta
}

Published online: 28 September 2011

(C) The Author(s) 2011. This article is published with open access at Springerlink.com

The price of gold reached 1891.90 US dollars per ounce during August 2011, suggesting that gold has found a new prominence in global financial markets and economics. An increasing number of people are currently protecting their capital in an asset that offers a safe store of value to today's investor. At the same time, the industrial applications of gold, largely centered on electronics (bonding wires, electroplating, etc.), have been growing and currently occupy around $12 \%$ of total gold demand. So a new gold rush is underway at the cutting edge of nanoscience and -technology research. A typical example is catalysis by gold. For over a century, gold in bulk form had been considered too noble to work as a catalyst. However, it has recently been proved that gold exhibits surprisingly high catalytic activity for many reactions when deposited as nanoparticles on base metal oxides, carbons, and polymers.

At the same time, gold colloids of different morphology are attracting growing interest owing to their special surface plasmonics; applications in DNA diagnosis, health care, and new paints are on the horizon. Coulomb blockade by quantum dots may present a new topic in electronics. Self-assembled monolayers on a substrate of gold are also an interesting area of research which functionalizes solid surfaces leading to catalysis, electrodes, and optoelectronics. These are just a part of the expanding science and technology of gold. Plenty of exciting discoveries and achievements are still emerging in other areas too, for example unexpected magnetism in gold nanostructures.

To discuss and debate this rapid growth of gold science and technology, the Gold 2012 conference will be held at one of the biggest terminals in the center of Tokyo, Shinjuku. Participants will enjoy a magnificent view from the 42nd and 43rd floors of the conference venue, the Keio Plaza Hotel. You are cordially invited to join us for this 6th Gold Conference, the first in Asia, after Heidelberg (2009), Limerick (2006), Vancouver (2003), Cape Town (2001), and Hanau (1996). Japan was once called the island of gold, Zipang, and it is now moving to the island to nanogold. Please join us at Gold 2012 in Tokyo to discuss mutual interests in nanotechnology, chemistry, catalysis, and nanomaterials of gold and its applications (www.gold2012.org)

M. Haruta

Chairman of the GOLD 2012 Organising Committee

Open Access This article is distributed under the terms of the Creative Commons Attribution License which permits any use, distribution and reproduction in any medium, provided the original author(s) and source are credited. 